\title{
Sütçü Manda Irklarının Performans ve Verimliliğini Etkileyen Faktörler ve Türkiye'deki Geleceği
}

\author{
Asiye Yilmaz Adkinson ${ }^{1}$, Yusuf Konca ${ }^{2 *}$ \\ ${ }^{1}$ Erciyes Universitesi, Ziraat Fakültesi, Zootekni Bölümü, 38039, Melikgazi-Kayseri, Türkiye, (ORCID:0000-0003-0311-5965), ayadkinson@erciyes.edu.tr \\ ${ }^{2 *}$ Erciyes Universitesi, Ziraat Fakültesi, Zootekni Bölümü, 38039, Melikgazi-Kayseri, Türkiye, (ORCID: 0000-0002-6231-1512), yusufkonca@erciyes.edu.tr
}

(Illk geliş tarihi: 13 Mart 2021 ve Kabul tarihi 4 Haziran 2021)

(DOI: $10.31590 /$ ejosat.896113)

ATIF/REFERENCE: Yılmaz Adkinson, A. \& Konca, Y. (2021). Sütçü Manda Irklarının Performans, Süt Verimini ve Kalitesini Etkileyen Faktörler ve Türkiye'deki Geleceği. European Journal of Science and Technology, (25), 498-508.

\section{Öz}

Manda başta Asya ülkeleri olmak üzere Dünya'da yetiştiriciliği yapılan önemli çiftlik hayvanlarından birisidir ve inekten sonra süt üretimine olan katkısı ikinci sırada yer almaktadır. Mandalar bataklık ve nehir mandası olarak iki ana gruba ayrılmaktadır. Nehir mandaları iri yapılı ve süt üretimi amacıyla yetiştirilirken bataklık mandaları daha küçük yapılı ve yük taşıma amacıyla kullanılmaktadır. Dünya'da 72 çeşit manda 1rkı vardır ve bunların 57'si Asya'da bulunmakta ve bunlar içerisinde süt üretimi için yetiştiriciliği yapılan 22 manda ırkı vardır. Manda ırkları arasında en yüksek süt verimi ile ilk sırada Akdeniz mandaları (900-4000 kg/laktasyon) ve bu 1rkı Mehsana ve Jafarabadi irkları (1800-2700 kg/laktasyon) takip etmektedir. Türkiye'de yetiştirilen Anadolu mandaları süt verim özellikleri (1000 kg/yıl) bakımından diğer manda ırklarına göre gerilerde yer almaktadır. Mandaların diğer ruminant hayvanlara göre düşük kaliteli meralardan ve kötü kaliteli kaba yemlerden yararlanma kabiliyetleri sığırlardan ve koyunlardan daha iyidir. Türkiye'de mandalardan elde edilen gelirin ana unsuru manda sütü ve süt ürünleridir. Manda kaymağı ve yoğurduna olan talebin fazla oluşu nedeniyle manda sütü sığır sütüne göre daha yüksek bir fiyatla satılmaktadır. Dünya'da manda yetiştiriciliği daha çok ekstansif şartlarda yapılmakta ve modern olmayan barınaklarda barındırılmaktadır. Bakım ve besleme şartlarındaki olumsuzluklar nedeniyle süt ve döl verimleri ineklere göre düşüktür. Ancak, İtalya'da olduğu gibi sslah ve iyi bakım ve besleme şartlarında verimlerinin yükseldiği ve elde edilen kar arttığını gösteren kayıtlar mevcuttur. Aynı zamanda, manda malakları da olumsuz şartlarda bakım ve beslemeye maruz kaldığından büyüme oranları düşük ve ölüm oranları yüksek olmaktadır. Bu çalışmada, bazı sütçü mandalar ile Anadolu mandalarının performans ve verim özellikleri incelenmiş ve Türkiye Manda üretiminin geliştirilmesinde katkı sağlayabilecek bazı tavsiyelerde bulunulmuştur.

Anahtar Kelimeler: Sütçü manda, süt üretimi, malak, gelecek stratejileri.

\section{Factors Affecting the Performance and Productivity of Dairy Buffalo Breeds and Future Perspective in Turkey}

\begin{abstract}
Water buffalo is one of the important farm animals that are grown especially in Asian countries and its contribution to milk production is in the second after cows in the world. Buffaloes are divided into two main groups as swamp and river buffalo. River buffaloes are large size and bred for milk production, while swamp buffaloes are smaller size and used for draught animals. There are 72 types of buffalo breeds in the world, 57 of which are in the Asia, and there are 22 buffalo breeds that are bred for milk production. The mediterranean buffaloes (900-4000 kg/lactation) are in the first breed with the highest milk yield among buffalo breeds, followed by Mehsana and Jafarabadi breeds (1800-2700 kg/lactation). The Anatolian buffaloes raised in Turkey are lower milk yield (1000 kg/year) than other buffalo breeds. Compared to other ruminant animals, the ability of buffaloes to benefit from poor quality pastures and low quality roughages are better than cattle and sheeps. The main element of income from buffaloes in Turkey is buffalo milk and dairy products. Due to the high demand for buffalo kaymak and yoghurt, buffalo milk is sold at a higher price than cow's milk. In the world, water buffalo breeding is mostly carried out in extensive conditions and housed in non-modern shelters. Due to the adverse conditions in the care and feeding, milk and progeny yields are lower than cows. However, in Italy, there are records showing increased yields and increased profits under good care and feeding conditions. At the same time, since buffalo calves are exposed to care and feeding under unsuitable conditions, their growth rates are low and mortality rates are high. In this study, performance and yield characteristics of some dairy buffaloes and Anatolian buffaloes were examined and some recommendations were made that could contribute to develop of Turkish buffalo production.
\end{abstract}

Keywords: Dairy buffalo, milk production, calf, future strategies.

\footnotetext{
*Sorumlu Yazar: yusufkonca@erciyes.edu.tr
} 


\section{Giriş}

Manda Bovidae familyasının sığırlar (Bovinae) alt familyasına ait bir memeli türüdür ve sınıflandırılmış iki türü vardır (Chantalakhana ve Bunyavejchewin, 1994). Bunlar Afrika yabani mandaları (Synceru) ve evcilleştirilen Asya mandalarıdır (Bubalus bubalis). Asya mandaları ise nehir mandaları (Bubalus bubalis bubalis) ve bataklık mandaları (Bubalus bubalis carabenesis) olarak iki alt türe ayrılmaktadır (Medhammar ve ark., 2012). Mandalar diğer çiftlik hayvanlarına göre kromozom sayıları bakımından önemli derecede farklılık göstermektedir. Nehir mandalarında 50 ve bataklık mandalarında 48 kromozom bulunmaktadır. Afrika mandaları da kromozom sayıları 52 ve 54 olan sirasiyla Cape manda (Syncerus caffer caffer) ve orman mandası (Syncerus caffer nonous) olarak ikiye ayrılırlar. Bu iki 1rk kendi arasında çiftleştirilmiş 53 kromozomlu mandalar elde edilmiştir ancak bunlardan elde edilen melez mandaların dengesiz gamet dağılım nedeniyle döl verimleri düşüktür (Iannuzzi, 2013). Türkiye'de yetiştirilen ırkın tamamı Anadolu mandasıdır ve nehir mandaları gibi 50 kromozoma sahiptir (Soysal, 2013). Kromozom sayısı nedeniyle sığırlardan (60 kromozom) önemli derecede farklılık gösterirler (Yavasoglu ve ark., 2014). Bataklık mandalarının tanınmış ırkları yoktur ve bunlar daha çok yük hayvanları olarak kullanılırlar ve süt verimleri de düşüktür, bunun aksine nehir mandaları süt üretim amacıyla kullanılırlar (Naveena ve Kiran, 2014).

Nehir mandaları dünyadaki manda varlığının yaklaşık \%70'ini oluşturmaktadır. Nehir mandaları Hindistan, Pakistan ve yakın doğudaki bazı ülkelerde süt üretiminin ana kaynağıdırlar (Naveena ve Kiran, 2014; Siddiky ve Faruque, 2018). Mandalar süt üretimi açısından süt ineklerinden sonra dünyadaki en önemli ikinci türdür ve yüksek kalitede süt üretirler (Coroian ve ark., 2013). Manda sütü öncelikle peynir, özellikle de İtalya'da mozzarella üretmek için kullanılır (Aspilcueta-Borquis ve ark., 2012). Manda sütünden yapılan peynirler tipik dokusal özellikler sergiler ve doğaları gereği benzersiz yapıları ve üstün duyusal niteliklere sahiptir (Hofi, 2013).

Dünya'da 72 çeşit manda ırkı vardır ve bunların 57'si Asya'da bulunmaktadır ve toplam manda varlığının \%97,1'i Asya kıtasında yetiştirilmektedir (FAOStat, 2019). Bazı Asya ülkelerinde üreticilerin en önemli ekonomik getiri kaynaklardan birisi mandalardan elde edilen gelirdir (Iannuzzi, 2013). Manda sütünün fiyatı, sığır sütünün yaklaşık üç katı kadar bir fiyata satılabilmekte (Rosati ve Van Vleck, 2002; Borghese, 2013) ve bu durumda karlılık artmaktadır.

Mandalar genellikle gelişmekte olan ülkelerde, ekstansif şartlarda, küçük ölçekli işletmelerde, çevrenin sunduğu imkanlara (otlak, anız, çalılar vb.) göre ve çoğu su kenarında otlayarak beslenmelerini sağlarlar (Boselli ve ark., 2010). Mandalar özellik olarak, düşük kaliteli kaba yemler ve kötü çevre koşullarına uyum sağlamaya yeteneklidirler ve çeşitli sığır hastalıklarına karşı daha dirençlidirler (Pasha, 2013). Bununla birlikte, mandaların dünyadaki yetiştirildiği bölgelere bakılmaksızın ineklere göre verimleri düşüktür. Mandaların geç ergenliğe ulaşması, zayıf östrus olgusu, doğum sonrası geç kızgınlık gösterme ve en önemlisi özellikle suni tohumlamada döl tutma oranın düşük olması üreme performansını azaltmaktadır (Phogat ve ark., 2016). İtalya'da geçmişi 50 yıldan önceye dayanan organizasyonlar ve yapılan çalışmalar manda yetiştiriciliğinde önemli ilerlemeler sağlanmasına neden olmuştur. Nitekim İtalya'da mandalardan bir laktasyonda alınan süt verimini artırmaya yönelik çalışmalar yanında, mozzaeralla peyniri veriminin iyileştirilmesine yönelik çalışmalar da sürdürülmektedir. Çünkü üreticinin geliri, ilk olarak mozzarella peyniri ve takiben gebe düve satışı, et üretimi ve son olarak yüksek genetik değere sahip sperma ve embriyo satışına dayanmaktadır (Borghese, 2013).

Bir kısım ülkelerin ana süt kaynağı ve gelirinde önemli bir paya sahip olan manda üretimi, ülkemizde de süt ve ürünlerinin fiyatının inek sütüne göre daha yüksek olması nedeniyle son yıllarda toplam sayısı ve süt üretimi önemli bir artış göstermiştir (TÜİK, 2020). Son zamanlarda damızlık manda düvesi yetiştiriciliğinin desteklenmesi amacıyla belli kriterleri sağlayan manda işletmelerine hibe desteği sağlanmaktadır (Resmi Gazete, Sayı: 31397). Ayrıca Tarım ve Orman Bakanlığı'nın anaç manda ve malak desteklemesi de bulunmaktadır (20/11/2019 tarih ve 30954 sayılı Resmi Gazetede yayımlanan 2019/54 No'lu Tebliğ). Üreticilere sağlanan bu destekler nedeniyle gelecek yıllarda manda sayısındaki artışın devam edeceği beklenmektedir.

$\mathrm{Bu}$ derlemede, sütçü manda ırklarının performans ve verim özellikleri yanında verimliliğini etkileyen unsurlar ve malakların bakım ve besleme yönetimi konularında bilgiler verilmiş ve Türkiye'de manda üretiminde izlenecek yollar konusunda önerilerde bulunulmuştur.

\section{2. Ülkelerin Manda Varlıkları ve Süt Üretimleri}

Hindistan dünya manda varlığının sayıca en çok olduğu ülkedir (toplamın \%54'ü) ve ikinci olarak Pakistan (\%20'sini) yer almaktadır (FAOStat, 2019). Hindistan'da yaygın 20 manda 1 rkı vardır ve bunlar içinde en yüksek süt verimine sahip olanları Murrah ve Nili-Ravi rrklarıdır (Nanda ve Nakao, 2003). Pakistan'da ise yaygın manda rrkları Nili, Ravi, Nili-Ravi melezi ve Kundi'dir (Hamid ve ark., 2016).

Manda sayısında olduğu gibi süt üretiminde de benzer bir yapı vardır ve dünya toplam manda süt üretiminin \%69'u, 92 milyon ton ile Hindistan'da yapılmakta ve bunu 34,4 milyon ton üretim ve \%26'lik pay ile ikinci sırada Pakistan izlemektedir (Tablo 1). Hindistan ve Pakistan dünya manda sütü üretiminin \%95'ini meydana getirmesine rağmen bu iki ülkedeki toplam manda sayısı dünyadaki manda sayısının \%73,4'ünü oluşturmaktadır. Türkiye manda sayısı bakımından 13. sırada ve süt üretimi bakımından 9. sırada yer almaktadır. Manda sütünün dünya süt üretimi içindeki payı \%15'tir ve bu oranla sı̆̆ır sütünden (\%81) sonra ikinci sırada yer almaktadır. Koyun, keçi ve deve sütünün dünya süt üretimindeki payı sırasıyla; \%1, \%2 ve $\% 0,35$ 'tir (FAOStat, 2019).

Türkiye'de azalan manda sayısı son yıllarda artarak yaklaşık 180 bin başa ve manda sütü üretimi 80 bin ton civarına ulaşmıştır (FAOStat, 2019). Türkiye'de manda sütünden üretilen kaymak ve manda yoğurdu pazarda en çok tercih edilen ürünlerdendir. İnek sütüne göre yaklaşık 2,25 kat ( çiftlik satış fiyatı; inek sütü 2,90

$\mathrm{TL} / \mathrm{kg}$, manda sütü 6,50 TL/kg, Kayseri Damızlık Manda Birliği görüşmesinden) daha fazla fiyatla alıcı bulmaktadır. Manda sütünden yoğurt, peynir, tereyağ 1 , kaymak, kaymak lokumu, dondurma, şekerleme ve sütlü tatlılar gibi katma değeri yüksek çok sayıda ürün elde edilmektedir. 
Tablo 1. Dünya'da ülkelere göre manda saylsl ve süt üretimi

\begin{tabular}{llll}
\hline Ülke & Manda Sayısı (baş) & Süt üretimi (bin ton) & Siralama \\
\hline Hindistan & 109851678 & 92000 & 1. \\
Pakistan & 40002000 & 34371 & 2. \\
Çin & 27336130 & 2928,369 & 3. \\
Nepal & 5308664 & 1372,905 & 4. \\
Myanmar & 4082914 & 204,750 & 5. \\
Misır & 3476396 & 2109,253 & 6. \\
Filipinler & 2873561 & Kayit yok & 7. \\
Vietnam & 2387887 & 27,211 & 8. \\
Bangladeş & 1490000 & 35,790 & 9. \\
Brezilya & 1434141 & Kayit yok & 10. \\
Endonezya & 1141298 & 85,474 & 11. \\
İtalya & 402290 & 249,450 & 12. \\
Türkiye & 178397 & 79,341 & 13. \\
Iran & 72434 & 128 & 14. \\
Dünya & 204342419 & 133752,296 & \\
\hline Kaynat: & & & \\
\hline
\end{tabular}

Kaynak: (FAOStat, 2019).

\section{Sütçü Mandaların Orijin, Renk, Büyüklük ve Süt Verim Özellikleri}

Mandalar bazı ülkelerde başlangıçta et, süt ve yük taşıma amaçlı kullanılan bir hayvan olarak kabul edilmiş, fakat sonraları süt üretimi için bazı manda rrkları geliştirilmiştir. Dünya'da süt üretim amaçlı kullanılan 22 adet süt ırkı manda bulunmaktadır (Mohran, 1991).

Manda ırklarının orijin, renk, büyüklük, ağırlık, süt verimi ve laktasyon uzunluğu Tablo 2'de verilmiştir. Manda ırkları arasında süt verimi en yüksek olan 1rk 900-4000 kg/laktasyon verimine kadar yükselen Akdeniz mandasıdır. Akdeniz mandasını Mehsana (Surti $\times$ Murrah melezi olarak elde edilen) 1rk1 (1800-2700 kg) ve Jafarabadi ırkı (1800-2700 kg) takip etmektedir. Misır mandası $1200-2100 \mathrm{~kg}$ süt verimi ve Surti mandas $2090 \mathrm{~kg} / \mathrm{laktasyon}$ süt verimi ile izlemektedir. Bu rrkları 2000, 2000, 1800, 1500, 700$1000 \mathrm{~kg}$ ve $781 \mathrm{~kg}$ ile sirasıyla Nili-Ravi, Kundi, Murrah, Pandharpuri, Anadolu ve Bhadawari ırkları izlemektedir.

Türkiye'de yetiştirilen Anadolu mandalarının süt verimleri ve canlı ağırlık (CA) değerleri diğer ırklara göre düşüktür. Diğer yandan süt ve et verimleri bakımından kombine olarak değerlendirilen Murrah, Nili-Ravi, Kundi, Surti, Jafarabadi ve Akdeniz manda ırklarının dişilerinin büyük yapılı mandalar grubuna girdiği ve bu irkların et üretimi için de uygun olduğunu göstermektedir (Tablo 2).
Manda türünün yetiştirildiği ve gıda üretiminde kullanıldığı İtalya, Romanya, Bulgaristan, Almanya, Makedonya, Birleşik Krallık, Yunanistan, Sirbistan, Arnavutluk, Ukrayna, Macaristan gibi AB ülkeleri içinde özellikle İtalya'nın süt üretimi, yönetim, beslenme ve üreme teknikleri, kaliteli gida ve pazarlama stratejilerinin üst düzeyde geliştiği görülmektedir.

İtalya'da 50 bin mandanın kayıtlarından 270 günlük laktasyon döneminde $2220 \mathrm{~kg}$ süt verimi elde edildiği ve sütlerde ortalama $\% 8,4$ yağ ve $\% 4,6$ protein içerdiği ve bir laktasyonda 5 tondan fazla süt veren çok sayıda manda bulunduğu bildirilmiştir (Borghese, 2013). Hindistan'da Murrah ırkından günde 14 ile18 $\mathrm{kg}$ süt elde edilmekte, elit olanlarda 18 ile $31,5 \mathrm{~kg} /$ gün süt verimi elde edilmiştir (Hamid ve ark., 2017).

İtalya'da manda sütünden üretilen ricotta, provola, scamorza, treccia ve diğer peynirler ile manda etinden üretilen biftek, rosto, jambon, bresaola, salam gibi pek çok ürün beğeni toplasa da hem İtalya ve hem de uluslararası pazarın en önemli ürünü mozzarella peynirleridir. İtalya'da her y1l 36 bin ton mozzarella peyniri üretilmekte ve 500 milyon Euro değerinde bir gelir elde edilmektedir. Mozzarellanın \%82'si İtalya'da tüketilirken \%18'lik bir kısım Almanya, Fransa, ABD, İngiltere başta olmak üzere diğer ülkelere ihraç edilmektedir (Borghese, 2013). Misır gibi bazı ülkelerde, yüksek fiyata rağmen daha güçlü duyusal özellikleri nedeniyle manda sütü tercih edilmekte ve ülkede üretilen bu sütün önemli bir kısmı içme sütü olarak kullanılmaktadır (Helal ve Abdel- Rahman, 2010).

Tablo 2. Manda ırklarının orijin, renk, büyüklük ve süt verim özellikleri ${ }^{1}$

\begin{tabular}{|c|c|c|c|c|c|c|}
\hline Irk & Orijin ülke & Renk & Büyüklük & $\begin{array}{l}\text { Ağırlık (dişi), } \\
\text { kg }\end{array}$ & $\begin{array}{l}\text { Süt verimi, } \\
\text { kg }\end{array}$ & $\begin{array}{c}\text { Laktasyon } \\
\text { uzunluğu, gün }\end{array}$ \\
\hline Akdeniz & İtalya & Siyah, kahverengi, koyu & Büyük & $450-600$ & $900-4000$ & 270 \\
\hline Mehsana & Hindistan & Siyah, gri, kahverengi & Orta & 430 & $1800-2700$ & 305 \\
\hline Jafarabadi & Hindistan & Black & Büyük & 550 & $1800-2700$ & 350 \\
\hline Misir manda & Misir & Siyah, kır & Orta & 500 & $1200-2100$ & $210-280$ \\
\hline Surti & Hindistan & Kızıl-gümüşi & Orta & $550-650$ & 2090 & 350 \\
\hline Nili-Ravi & Hindistan/ & Siyah & Büyük & 600 & 2000 & 305 \\
\hline Kundi & Pakistan & Siyah & Büyük & 600 & 2000 & 320 \\
\hline Murrah & Hindistan & Parlak siyah & Büyük & 650 & 1800 & 305 \\
\hline Pandharpuri & Hindistan & Siyah & Orta & 450 & $1500 *$ & $350 *$ \\
\hline Anadolu & Türkiye & Siyah & Orta & $200-500$ & $700-1000$ & $220-270$ \\
\hline Bhadawari & Hindistan & Bakır veya gri siyah & Orta & 425 & $781 * *$ & $272 * *$ \\
\hline
\end{tabular}

${ }^{1}$ (Moioli ve Borghese, 2005), *(Ambardekar, 2000), **(Moioli and Borghese, 2005'den naklen Sethi, 2003). 


\section{Sütçü Manda Irklarının Döl Verim Özellikleri}

Çeşitli manda 1rkların doğum ve kuruda kalma gibi döl verimine ilişkin özellikleri Tablo 3 'te verilmiştir. Mandaların döl verimleri ve bununla ilişkili olarak ilk malaklama yaşı, malaklama aralığı ve kuruda kalma sürelerinin de dikkate alınması gereklidir. Malaklama aralığı, çiftliklerde doğurganlık indeksi olarak kullanılan önemli bir parametredir. Mandalar genellikle üç yılda iki yavru verirler, ancak iyi yönetim ve besleme koşullarında sürülerde 11-12 aylık malaklama aralıkları sağlanabilir. Süt üretimi amaçlı yetiştirilen nehir mandalarında, malaklama aralığı büyük ölçüde üreme yılı ve mevsimi (Gwazdauskas ve ark., 1975) ile çiftlik yönetimi ve sürü büyüklügüune bağlı olarak değişebilmektedir. Pandharpuri manda 1rkı, üreme kabiliyetinin yüksek olmasıyla ünlüdür ve her 12-13 ayda bir malak üretirler (Ambardekar, 2000).

Mandalarda malaklama aralıkları ırklara ve bakım yönetim uygulamalarına göre önemli miktarda değişebilmektedir. Tablo 3 'te görüldüğ̈̈ gibi malaklama aralığ 402 ila 556 gün arasında değişmiştir. Rathod ve ark. (2018) Hindistan mandalarında malaklama aralığındaki büyük değişkenlik bulunduğu ve bu değişkenliklerin doğum sonrası kızgınlık, besleme ve yönetim uygulamalarıyla azaltılabileceğini bildirilmiştir. $\mathrm{Bu}$ tür özelliklerdeki değişkenliğin azalması, yaşam süresi boyu üretim artışı için de oldukça önemlidir.

Salari ve ark. (2013) birden çok doğum yapmış mandalara göre bir kez doğum yapmış Akdeniz manda ineklerinin \%12 daha fazla süt verdiklerini $(8,47 \mathrm{~kg} /$ gün$)$, süt üretiminin 16 ile 60 günler arasında arttığını (11,35 kg /gün/ baş) ve laktasyon sonundaki süt yağ $1(\% 8,64)$ ve protein oranının pik verim dönemine göre daha yüksek olduğunu $(4,84$ 'e karşı 4,93) bildirmişlerdir.

Anadolu mandalarında malakların doğum ağırlığı, annenin canlı ağırlığı ve yaşının artışıyla önemli ölçüde artmaktadır. Ayrıca, erkek malakların doğum ağırlığı dişi malaklardan daha yüksek olmaktadır (Uğurlu ve ark., 2016). Kış-ilkbahar döneminde doğum yapan mandaların toplam süt verimi ve laktasyon uzunluğu yaz-sonbahar dönemine göre daha yüksek bulunmuştur (Uğurlu ve ark., 2016; Ekiz ve ark., 2018). Farklı fenotipik özellikler ile süt üretimi arasındaki ilişkiyi belirlemek için yapılan çalışmalar, siyah renkli dişi mandaların koyu kahverengi renkli dişilerden daha fazla süt ürettiğini göstermiştir $(2195 \pm 34$ 'e karşı $1863 \pm 30 \mathrm{~kg})$. Buna karşılık hayvanların boynuz şekilleri ve boylarının süt verimi ile ilişkisinin bulunmadığ süt verimi $(2120 \pm 27 \mathrm{~kg})$, gergin olanlardan $(1829 \pm 49 \mathrm{~kg}) \mathrm{ve}$ agresif (1743 $\pm 147 \mathrm{~kg})$ olanlardan daha yüksek olmuş ve deri kalınlığı arttıkça süt veriminin azaldığı belirlenmiştir (Bharadwaj ve ark., 2007).

Tablo 3. Farklı manda ırklarının üreme özellikleri

\begin{tabular}{|c|c|c|c|c|c|c|}
\hline Irklar & $\begin{array}{ll}\text { Süt } & \text { verimi, } \\
\mathrm{kg} & \end{array}$ & $\begin{array}{l}\text { Günlük süt } \\
\text { verimi }\end{array}$ & $\begin{array}{l}\text { Malaklama aralığı, } \\
\text { gün }\end{array}$ & $\begin{array}{l}\text { Laktasyon } \\
\text { uzunluğu, gün }\end{array}$ & $\begin{array}{l}\text { Kuru dönem, } \\
\text { gün }\end{array}$ & $\begin{array}{l}\text { İlk malaklama } \\
\text { yaşı, gün }\end{array}$ \\
\hline $\begin{array}{l}\text { Kundi (Ghaffar ve ark., } \\
\text { 2007) }\end{array}$ & 1357 & 6,19 & 556,15 & 218,72 & 347,64 & 1123,18 \\
\hline $\begin{array}{l}\text { Kundi (Bilal ve ark., } \\
\text { 2006) }\end{array}$ & 2315 & 7,12 & 551 & 325 & 226 & 1640 \\
\hline $\begin{array}{l}\text { Nili Ravi (Bilal ve ark., } \\
\text { 2006) }\end{array}$ & 2430 & 7,27 & 512 & 322 & 190 & 1390 \\
\hline $\begin{array}{l}\text { Akdeniz (Rosati ve Van } \\
\text { Vleck, 2002) }\end{array}$ & 2287 & 8,47 & - & 270 & - & - \\
\hline $\begin{array}{l}\text { Surti (Rathod ve ark., } \\
\text { 2018) }\end{array}$ & 898,8 & 3,54 & 456,09 & 254,30 & 212,36 & 1373,52 \\
\hline $\begin{array}{l}\text { Murrah (Charlini ve } \\
\text { Sinniah, 2015) }\end{array}$ & 1249 & 4,19 & 479 & 298 & 180 & 1845 \\
\hline $\begin{array}{l}\text { Nili-Ravi (Charlini ve } \\
\text { Sinniah, 2015) }\end{array}$ & 1187 & 4,99 & 412 & 238 & 181 & 1329 \\
\hline $\begin{array}{l}\text { Surti (Charlini ve } \\
\text { Sinniah, 2015) }\end{array}$ & 1197 & 4,17 & 489 & 287 & 185 & 1311 \\
\hline $\begin{array}{l}\text { Mehsana (Galsar ve ark., } \\
\text { 2016) }\end{array}$ & 1708.62 & 5,95 & 460,97 & 298,84 & 165,35 & 1551,31 \\
\hline $\begin{array}{l}\text { Anadolu (Soysal ve ark., } \\
\text { 2018) }\end{array}$ & 1223,9 & 5,30 & 417,51 & 230,99 & - & - \\
\hline $\begin{array}{l}\text { Anadolu (Alkoyak ve } \\
\text { Öz, 2020) }\end{array}$ & 1035,5 & 3,98 & 426,35 & 260,26 & - & - \\
\hline $\begin{array}{l}\text { Misir (Marai ve ark., } \\
\text { 2009) }\end{array}$ & 1590,0 & 6,52 & 402,6 & 244,1 & 148,7 & 753 \\
\hline $\begin{array}{l}\text { Anadolu (Şekerden ve } \\
\text { Küçükkebapçı, 1999) }\end{array}$ & 1070 & 4,84 & 387 & 221 & - & 1313 \\
\hline $\begin{array}{l}\text { Anadolu (Koçak ve ark., } \\
\text { 2019) }\end{array}$ & 1087 & 4,44 & 450 & 245 & - & - \\
\hline
\end{tabular}




\section{Manda Irklarının Süt Kompozisyonları}

Farklı manda ırklarının süt kompozisyonları Tablo 4'te verilmiştir. Manda sütü sahip olduğu özellikleri sütteki yağ, kuru madde, protein ve kazein değerlerinden almaktadır. Mandalarda süt veriminin yüksek olması arzulanan bir durumdur. Ancak, mandaların ineklere göre düşük süt verimine rağmen üretimlerine devam ettirilmesi, elde edilen gelirin süt ürünlerinin yüksek fiyata satılarak tatminkâr bir gelir elde edildiğinden kaynaklanmaktadır (Borghese, 2013; Rosati ve Van Vleck, 2002).

Tablo 4'ün incelenmesinden mandalardan süt proteini en düşük \%3,3 (Nili-Ravi ırkında) ve en yüksek \%5,4 (Mehsana ırkında) arasında olduğu tespit edilmiştir. Yağ bakımından en yüksek oran \%8,8 ila Jafarabadi ırkında ve en düşük olarak \% $\%, 98$ ile Nili-Ravi ve Anadolu mandasında olduğu görülmektedir. Laktoz bakımından en düşük değerler Nili-Ravi ırkına ve en yüksek değerler ise Anadolu mandası ırkına ait olmuştur. Kuru madde bakımından ise en düşük değer \%14,96 ile Surti ırkında ve en yüksek değer \%19,03 ile Murrah ırkında elde edilmiştir. Kül bakımından ise en düşük değer \%0,67 ile Anadolu mandasında ve en yüksek değer \%1,01 ile Nili-Ravi'den elde edilmiştir. Kazein bakımından ise en düşük değer \%3,07 ile Mehsana ırkında ve en yüksek değer \%4,43 ile Murrah 1rkından elde edilmiştir. Yağsız kuru madde (SNF) bakımından en düşük değer \%8,67 ile NiliRavi ırkında ve en yüksek değer \%11,50 ile Bhadawari ırkında elde edilmiştir. Süt Ph'sı bakımından ise en düşük değer \%6,54 ile Murrah ırkında ve en yüksek değer \%6,90 ile Jafarabadi ırkından elde edilmiştir.

Tablo 4. Farklı manda 1rklarının süt kompozisyonları

\begin{tabular}{|c|c|c|c|c|c|c|c|c|c|}
\hline & Yazar & $\begin{array}{l}\text { Protein, } \\
\%\end{array}$ & $\begin{array}{c}\text { Yağ, } \\
\%\end{array}$ & $\begin{array}{c}\text { Laktoz, } \\
\%\end{array}$ & $\begin{array}{c}\text { Kuru } \\
\text { madde, \% }\end{array}$ & $\begin{array}{l}\text { Ham } \\
\text { kül, \% }\end{array}$ & $\begin{array}{c}\text { Kazein } \\
\%\end{array}$ & $\begin{array}{l}\text { Yağsiz kuru } \\
\text { madde, \% }\end{array}$ & $\mathrm{pH}$ \\
\hline Akdeniz & (Costa ve ark., 2020) & 4,49 & 7,95 & 4,78 & - & - & - & - & 6,75 \\
\hline Mehsana & (Misra ve ark., 2008) & 3,87 & 6,46 & - & 15,59 & - & 3,07 & 9,13 & - \\
\hline Surti & (Misra ve ark., 2008) & 3,93 & 6,17 & - & 14,96 & - & 3,11 & 8,80 & - \\
\hline Jafarabadi & (Patiño ve Guaziroli, 2005) & 5,20 & 8,8 & 4,55 & 18,42 & 0,78 & - & - & 6,90 \\
\hline Murrah & (Wang ve ark., 2019) & 4,76 & 7,48 & 4,76 & 17,80 & 0,8 & 4,43 & - & 6,54 \\
\hline Nili-Ravi & (Wang ve ark., 2019) & 4,38 & 7,31 & 4,73 & 17,21 & 0,8 & 4,04 & - & 6,55 \\
\hline Nili-Ravi & (Javed ve ark., 2013) & 3,3 & 5,98 & 4,58 & - & 0,83 & - & 8,67 & - \\
\hline Nili-Ravi & (Nawaz ve ark., 2007) & 3,9 & 7,74 & 4,14 & - & 1,01 & - & 9,05 & - \\
\hline Murrah & (Zhou ve ark., 2018) & 4,92 & 7,82 & 5,18 & 19,03 & & - & - & - \\
\hline Nili-Ravi & (Zhou ve ark., 2018) & 4,54 & 6,77 & 5,28 & 17,74 & & - & - & - \\
\hline Surti & (Kapadiya ve ark., 2016) & 4,48 & 8,30 & 4,86 & 18,45 & 0,81 & - & 9,48 & - \\
\hline Murrah & (Barbosa ve ark., 2020) & 4,01 & 6,99 & 4,72 & 16,85 & - & - & - & - \\
\hline Anadolu & (Sahin ve ark., 2016) & 4,85 & 5,98 & 5,17 & 16,99 & - & 3,61 & - & - \\
\hline Anadolu & (Yilmaz ve ark., 2017) & 3,40 & 7,09 & 4,57 & 16,08 & 0,67 & - & - & 6,68 \\
\hline
\end{tabular}




\section{Sütçü Mandaların Canlı Ağırlık ve Yem Değerlendirme Özellikleri}

Çiftlik hayvanlarında CA, canlı ağırlık artışı (CAA), yem tüketimi ve yemden yararlanma performansları ekonomik olarak dikkate alınan önemli özelliklerdendir. Hayvanlar tükettikleri yemleri öncelikle yaşama payı ve geri kalan kısmını da verim payı olarak kullanırlar. Canlı ağırlık artıkça, çevre ısısı hayvan istek sınırlarından uzaklaştıkça, hastalık ve parazitlerin mevcudiyeti gibi durumlarda hayvanların yaşama payı gereksinimi artar ve verim için kullanılacak besin madde miktarı azalır. Hayvanlar bazen yüksek verimi devam ettirmek için vücutlarından bir miktar depo besin maddelerini kullansalar da yaşamın tehlikeye gireceği noktaya gelindiğinde verim azalır ve hayatta kalma fonksiyonu ön plana geçirilir. Karlı bir hayvancılıkta yemin ürüne dönüşme oranı, karlılığı ve dolayısıyla sürdürülebilirliği etkileyen en önemli faktörlerdendir. Yemin süte dönüşüm oranı (yemden yararlanma kabiliyeti) bakımından değerlendirildiğinde, aynı miktar süt veren hayvanlardan CA'1 yüksek olanların yaşama payı daha yüksek olduğu için daha çok yem tüketimi gerekecektir ve aynı süt verimine sahip zayıf yapılı bir hayvan daha karlı olabilecektir. Ancak, hayvanların eti ve sütünden birlikte yararlanılıyorsa, o zaman süt verimi ve CA'1 yüksek hayvanlar kombine verim için tercih edilirler. Tablo 2'de görülebileceği gibi mandalarda hem CA ve hem de süt verimi yüksek olan (Murrah, Akdeniz, Surti ve Nili-Ravi gibi) 1rklar bulunmaktadır. Bunların et ve süt gelirleri doğal olarak daha yüksek olacaktır.

Mandaların kuru madde tüketimi, genellikle süt sığırlarına göre daha düşüktür (Terramoccia ve ark., 2000). Manda düveleri, otlakta tutulduğunda, karışık rasyonlarla beslenen kapalı ortamlarda yetiştirilen hayvanların gösterdiği benzer üretim ve üreme performansları gösterebilirler (Sabia ve ark., 2015). Yapılan bazı çalışmalarda mandaların sığır ve koyunlara göre selüloz ve proteinden daha iyi yararlandıkları gösterilmiştir (Sarwar ve McDonough, 1990). Mandaların düşük kaliteli yemleri sindirim üstünlükleri, kötü şartlara karşı adaptasyon kabiliyetlerinin yüksekliğini de göstermektedir.

Mandalar Asya ülkelerinde geleneksel yöntemlerle kötü şartlarda barındırılmakta ve beslenmektedir. Bununla birlikte mandaların çevre bakım ve beslenme şartlarının iyileştirilmesi süt veriminde artışa neden olabilmektedir. Nitekim yapılan bir çalışmada, doğumuna 60 gün kalmış olan gebe Surti mandaları ikiye ayrılmış ve kontrol grubu hayvanlara sadece yem verilirken diğer gruba içinde konsantre yem olan ilave yem verilmiştir. Mandalar doğum öncesi her iki grupta benzer miktarda kuru madde yem tüketmişler ancak doğum sonrası konsantre yem verilen grupta kuru madde tüketimi (10,77 kg'a karşın $12,33 \mathrm{~kg}$ ) ve günlük süt verimi artış göstermiştir (2.16'ya karşın 3,61 $\mathrm{kg} / \mathrm{gün}$ ). Ancak, gruplar arasında yağ, laktoz, süt proteini, yağsız kuru madde, vücut kondisyon skoru ile malak doğum ağırlıkları benzer bulunmuştur. Net gelir muamele grubunda kontrol grubuna göre daha yüksek bulunmuştur. Neticede Surti mandalarına ilave yemleme yapmak erken laktasyon döneminde üretim performansını artırmış ve daha ekonomik bir üretim sağlamıştır (Raval ve ark., 2019).

Asya ülkelerinde mandaların ana yiyecek kaynaklarından birisi yüksek miktarda lignin içerikli sindirim oranı düşük samanlardır. $\mathrm{Bu}$ ülkelerde yağışların yıl içindeki dağılımı nedeniyle, düzensiz yem üretimi ve düşük kaliteli kaba yemlerle hayvanların beslenmeleri sonucunda düşük performans ortaya çıkmaktadır. Son yıllarda, mandaların beslenmesinde kullanılan e-ISSN: 2148-2683 yemlerin çeşitlendirilmesi ve yerel yem kaynaklarının sindirim derecelerinin artırılmasına yönelik olarak kullanılan yem katkıları ve uygulanan diğer yöntemler hayvanların beslenmelerinde bir miktar iyileşmeler sağlamıştır (Sarwar ve ark., 2009; Wynn ve ark., 2009). Hayvanların beslenmelerinde meydana getirilecek iyileşmeler, süt verimi yanında döl verimini artırabilir ve ilk malaklama yaşı ve aralığını da düşürülebilir (Qureshi ve ark., 2002; Drost, 2007).

İlk malaklama yaşının geç olması mandalar için bir karakteristik özelliği değildir, fakat büyüme dönemindeki besleme yönetimi ile yakından ilişkilidir. Büyüme döneminde hayvanlar yeterli CAA gösterirlerse ilk malaklama yaşındaki gecikme de azalmaktadır (Qureshi ve ark., 2002). Mandalarda iyi bir büyüme sağlamak için, doğumla birlikte iyi bir besleme stratejisi uygulanması gereklidir. Günlük CAA yüksek (631 g/gün) olan manda düvelerinde ilk kızgınlık görülme süresi daha kısa (598 gün) iken düşük CAA kazananlarda (441 g/gün) bu süre (658 gün) uzamaktadır (Borghese, 2005).

Kış mevsiminde soğuk ve sert rüzgarlar ve düşük sıcaklıkta aşırı yağışlara maruz kalma, yaz mevsiminde de gölgeliğin veya hayvanın içine girebileceği su birikintilerinin olmadığ durumlarda yüksek oksidatif stresin oluşması neticesinde üreme etkenliğinde başarısızlıklara neden olabilmektedir (Zicarelli ve ark., 2007). Hayvanlarda oksidatif stresin önlenmesinde bazı vitaminler sıklıkla kullanılmaktadır. Yapılan bir çalışmada (Nayyar ve ark., 2002), rasyonda vitamin E bulunmasının oksidatif strese karşı hayvanları daha güçlü yaptığını ve servis periyodunu kısalttığı, diğer bir çalışmada da (Panda ve ark., 2006), rasyona E vitamini ilavesinin doğum sonrası kızgınlık aralığını ve kuruda kalma süresini azalttığ şekilde El-Barody ve ark. (2001) niasin ilavesinin de malaklama aralığını azalttığını, doğum sonrası tekrar kızgınlık oranını artırdığını ve kuruda kalma dönemini kısalttığını göstermişlerdir.

Ruminant hayvanların kızgınlık döngülerini düzenli bir şekilde devam ettirebilmeleri için başta enerji olmak üzere protein ve diğer besin maddelerince yeterli beslenmeleri gerekir. Saman ve düşük kaliteli yemlerle ağırlıklı olarak beslenildiğinde hayvanların gereksinimi olan yeterli besin maddeleri temin edilemez ve bu nedenle ovulasyonda gerekli olan FSH ve $\mathrm{LH}$ hormonlarının düzenli salınımı gerçekleşmez (Aksoy ve ark., 1981). Mandaların bilhassa kış dönemlerinde tamamen kalitesiz kaba yemlere dayalı beslenmeleri kızgınlığ 1 azaltan önemli bir faktör olacağı düşünülmelidir. Yüksek süt verimli mandaların besin madde gereksinimleri de yüksektir ve bu ihtiyaçlar ancak günlük verilen konsantre yem miktarını artırarak karşılanabilir. Bununla birlikte rasyonda yüksek konsantre oranı rumende düşük asetat/propiyonat oluşumuna neden olarak rumen asidozunu artırmakta ve süt verimi ve yağının azalmasına neden olmaktadır (Andersen ve ark., 1999).

Warriach ve ark. (2015) optimum şartlarda nehir mandaları 15-18 aylık yaşlarda bataklık mandaları ise 21-24 aylık yaşlarda cinsi olgunluğa eriştiklerini bildirmişlerdir. Bununla birlikte, cinsi olgunluk yaşı, genetik, iklim şartları, bakım ve besleme şartları cinsi olgunluk yaşını etkiler. Ticari sığır üretiminde kullanılarak yapılan östrus ve senkronizasyon uygulamaları mandalarda da yapıldığında doğal koşullara göre gebelik oranı \%30 ila 50 oranında artırılabilmektedir. Ticari mandaların ilk malaklama yaşının geç olması, kızgınlık belirtilerinin az ve düzensiz görülmesi (Şekerden ve ark., 2005), kızgınlık ve uzun malaklama aralıkları ve uzun süren kuru dönem süresi nedeniyle süt verimini etkileyen önemli sayıda faktör bulunmaktadır (Borghese, 2005). 
Mandalarda önemli problemlerden birisi de sağım sistemine alışmalarının zor olması, dolayısıyla sağımla ilgili otomasyona uyumlu olmamalarıdır (Sannino ve ark., 2018). Bunun yanında, pratikte yetiştiriciler ilk doğumda makinalı sağıma alıştırıldığında, sağımın makine ile sürdürülebildiğini belirtmektedirler. Mandaların sağım sistemlerine uyumdaki zorlukları ve sütü daha geç indirmeleri, meme anatomisi, süt salma mekanizması, meme dokularının iç yerleşimi ve uzun ve ince meme başı yapısından kaynaklanmaktadır (Thomas ve ark., 2004; Allegrini ve ark., 2007). Bununla birlikte, makine ile sağımlarda süt verimi miktarının arttığı, pik süt veriminde daha uzun süre kaldığ 1 , sütlerinin daha yüksek protein ve kazein içerikleri ve daha düşük bakteri ve somatik hücre sayısına sahip oldukları bildirilmiştir (Sannino ve ark., 2018).

Mandaların besin madde içeriklilerine ilişkin NRC veya diğer kuruluşlar tarafindan yayınlanmış bir veri tablosu bulunmamaktadır. Manda ve malaklarının beslenmesi ile ilgili olarak tavsiye edilen değerlere https://agritech.tnau.ac.in/ (TNAU, 2020) sitesinde rastlanılmıştır. Çeşitli yayınlarda mandaların kuru madde (KM) ihtiyaçlarının sığırlar için verilen değerlerden (canlı ağırlı̆̆ın \%2,57'sine karşılık \%3,09) daha düşük olduğu belirtilmektedir (Sarwar ve ark., 2009; Paul ve ark., 2003). Aynı zamanda mandaların yem proteini ve enerjisinden yararlanma etkinliği sığırlardan daha yüksektir ve dolayısıyla her $\mathrm{kg}$ \%4 yağlı süt ve her kg canlı ağırlık artışı için sığırlara göre daha düşük protein ve enerji tüketmektedirler (Paul ve ark., 2003). Jabbar ve ark. (2013) Nili Ravi mandaları ile yaptıkları çalışmada, mandaları sığırlar için NRC (2001)'de önerilen ME değerlerinin $\% 100, \% 80$ ve \%120'si kadar enerji sağlanan yemlerle beslemişılerdir. Araştırıcılar, çalışma sonuçlarına göre sığırlar için önerilen ME değerlerinin mandalar için de kullanılabileceğini bildirmişlerdir.

Malaklar için 0-15, 15-30, 30-60 ve 60-90 günlük yaşlar için önerilen sindirilebilir ham protein gereksinimi 80, 90, 120 ve 150 g/gün; metabolik enerji (ME, Mcal) ihtiyaçları, 1,5, 1,7, 2,4 ve 3,6; kalsiyum (Ca) ihtiyaçları 2,5, 3,0, 3,5 ve 4,0 g/gün ve fosfor (P) gereksinimleri 1,5, 2,0, 2,5 ve 3,0 g/gün olarak verilmiştir. Yetişkin 450, 500 ve $600 \mathrm{~kg}$ canlı ağırlıkta bulunan mandalar için günlük önerilen ham protein (HP), metabolik enerji (ME, Mcal), kalsiyum ve fosfor ihtiyaçları sırasıyla; 341, 364,406 g HP, 13, 14,2 16,3 Mcal ME, 18, 20, 24 g Ca ve 13,14 ve 17 g P'dur. Ayrica sağılan mandalarda bu besin maddelerine ilaveten her $\mathrm{kg} \% 4$ yağlı düzeltilmiş süt verimi için $90 \mathrm{~g} \mathrm{HP}, 1,24 \mathrm{ME}$ (Mcal), 2,73 Ca ve 1,68 P ilave edilmelidir (TNAU, 2020).

\section{Sütçü Manda Malaklarının Bakım ve Beslenme Yönetimi}

Büyükbaş hayvan üretiminde sağlıklı yavruların doğumu, üreme ve süt üretimi verimliliğinin bir işareti olarak kabul edilir. Nehir mandaları yaklaşık 310 günlük gebelik döneminden sonra bir malak (veya nadiren ikiz) doğurur. Fizyolojik etkiler nedeniyle doğum süreci stresli olarak kabul edilir ve anormal doğumlarda ek stresler ortaya çıkabilir. Stresin şiddeti birçok faktöre bağlıdır ve hayvanın refahını ve süt verimini olumsuz etkileyebilir (Purohit ve ark., 2012). Entansif yetiştirme sistemlerinde malaklar annelerinden doğumdan 24-48 saat sonra ayrılırlar. Bu erken ayrılış hem annelerde hem de malaklarda strese neden olur (MotaRojas ve ark., 2019).

Manda işletmelerinde sürünün yenilenmesi ve yüksek canlı ağırlık kazancı için etkili bir malak yemleme sisteminin yapılması gereklidir. Bununla birlikte manda üreticiliğinde analarının e-ISSN: 2148-2683 beslenmesi ihmal edildiği gibi malakların da yetersiz kolostrum tüketimi ve sonraki dönemde beslenmesi ihmal edilebilmekte ve bunun sonucu olarak yüksek malak ölümleri meydana gelmektedir (Wynn ve ark., 2009). Manda yetiştiriciliği yapılan birçok bölgede süt fiyatlarının pahalı olması, malaklara verilen süt miktarının kısıtlanmasına neden olmakta ve üreticiler erken sütten kesmektedirler.

İtalyan mandalarının beslenmesinde süt yanında bir miktarda konsantre yem verilmekte ve bu sayede malak ölüm oranları Asya ülkelerine göre daha düşük olmaktadır (Purohit ve ark., 2012; Mota-Rojas ve ark., 2019). Malakların doğumda annelerinden ayrılması, doğumlarından birkaç saat sonra kaliteli kolostrum ile beslenmesi ve ardından biberon kullanılarak uygun miktarlarda süt verilmesi durumunda manda malaklarındaki ölüm oranlarının azaltılabileceğini saptanmıştır (Ranjhan, 2007). Yetersiz besleme, manda düvelerinde yüksek ölüm ve ergenlik çağında gecikme ile sonuçlanmakta, dengeli besleme ve iyi yönetim uygulamaları ise hastalık görülme oranın azalmasına ve ilk malaklama yaşının kısaltılmasına neden olmaktadır. Genç malaklarda yüksek ölüm oranları ve erkek manda malaklarının işletmeden atılması, kaliteli genetik materyalin kaybına neden olur (Bharti ve ark., 2015). Malaklara verilecek süt miktarı ve malakların sütten kesilme süresi ve etkileri en önemli konular arasındadır. Malakların doğum sonrası ilk yarım saat sonrasından başlayarak 8 saat içinde yeterli kolostrum alması aktif bağışıklığın sağlanması için şarttır. Modern süt sığırcılığı işletmelerde yavru anasıyla kısa bir süre birlikte kalabilir ve kolostrumu aldıktan sonra 3-4 gün içerisinde farklı bir bölmeye alınır ve burada analardan sağılan sütler yavrularına biberon yardımıyla verilir. Malakların ana ile tutulduğu durumlarda veya malağın sağım saatlerinde farklı bölmelerden ananın yanına getirilmesi ve içilen sütün miktarının kontrol edilememesi bir kısım yönetim zorluklarına neden olmaktadir.

Mandaların sığırlardan farklı olarak, annenin sütü indirmesi için malak tarafından uyarılmasına gereksinim bulunmaktadır (Kumar ve ark., 2017). Özellikle bazı manda irklarda mandaların malakla birlikte olmadığında süt salma işlemi başlamamaktadır. Nitekim İtalya'da ölen yavruların derileri yüzülerek bir başka malağın üzerine konularak kokusu vasıtasıyla süt salınımını indirmek için kullanılmaları malak-ana interaksiyonunu ortaya koymaktadır (Mota-Rojas ve ark., 2019).

Manda malaklarının beslenmesinde yaygın olarak analarından doğrudan emzirme yöntemleri kullanılmaktadır, çiftçiler sütten kesim süresi ve içecekleri süt miktarını, sütün fiyatına göre değiştirebilmektedirler. Normal şartlarda malakların sütten kesim süresi 8-12 hafta ve içecekleri süt miktarı canlı ağırlığın \%10’u civarındadır. Manda sütünün içme sütü olarak kullanıldığ ve inek sütünün 2 katı fiyatla satılan yerlerde ve İtalya gibi manda sütünden mozzarella peyniri yapılan ve inek sütünün 3-4 katı fiyatla satıldığ 1 yerlerde daha erken sütten kesme eğilimi meydana geldiği belirlenmiştir (Zicarelli, 2020). Manda malaklarında verilecek süt miktarı ve süresi ile ilgili yapılan bir çalışmada, (Abbas ve ark., 2017) CA'ın \%10 (düşük) ve \%15'i (yüksek) kadar ve kısa ve uzun süreli (56 ve 84 . günde) sütten kesim süresi uygulanan malaklarda bol süt verilen ve uzun süre sütle beslenen malakların büyüme performanslarının daha yüksek olduğu bildirilmiştir. Rashid ve ark. (2013) manda malaklarının büyüme performanslarından kayıp olmaksızın 56 günde başarıyla sütten kesilebileceğini bildirmiştir.

Manda malaklarının emzirilmesi bazı avantajlı ve dezavantajlı durumlar ortaya çıkarmaktadır. Avantajlı durum olarak, anasını emen malaklarda kanda yüksek immunoglobulin seviyesinin oluştuğu (Abbas ve ark., 2017; Khan et al., 2007), 
daha az ishal vakaları görüldüğü (Aref ve ark., 2016), daha yüksek canlı ağırlık kazanıldığı ve vücut ölçülerinin arttığı, analarda süt salınım süresinin kısaldığı, süt akış hızının ve süt veriminin arttığ bildirilmiştir (Kumar ve ark., 2017). Malakların analarını emmeye devam etmesi durumunda anaların doğum sonra kızgınlık göstermeleri ve ilk tohumlama gecikmektedir, erken anneden ayrılanlarda kızgınlık gösterme süresi azalmaktadır ve tohumlama başına gebelik oranı artması gibi (Bharti ve ark., 2015) dezavantajları vardır. Eğer malaklar doğum sonrasında analarından hemen ayrılırlarsa sağımda anaların gerginliği daha yüksek olmakta (de la Cruz-Cruz ve ark., 2019), malaklar daha fazla sağlık problemi yaşamakta, büyüme hormonu ve kan glikoz seviyesinin düştüğü (Aref ve ark., 2016), ahır ekipmanlarını ve birbirlerini yalama eğilimin arttığı ve bögürme sayılarının azaldığı tespit edilmiştir (Bharti ve ark., 2015).

Malakların geleneksel sistemlerle emzirilmek suretiyle beslenmeleri durumunda harcanan süt maliyeti, malağın sütten kesimdeki satış maliyetinden daha yüksek olabilmektedir. $\mathrm{Bu}$ nedenle bazı çiftlikler, yeni doğan malakları beslemek yerine, sütü satmayı tercih etmektedir ve erkek malakları sadece annesinin sütü indirmesi için elde tuttukları ve eğer annenin yavrusuz süt verme durumu varsa onları boğa yapmak yerine çiftlikten atmayı tercih ettikleri bildirilmiştir (Bhatti ve ark., 2009). Süt ikame yemleri ile beslemenin maliyeti azalttığını, ancak sütle beslenenlere göre daha düşük CA elde edildiğini belirlemişlerdir (Bhatti ve ark., 2012). Rafiuddin ve ark. (2009) grup büyüklüğünün manda malaklarının büyüme performansı ve sağlık parametrelerine olan etkilerini inceledikleri çalışmada; bölmede 1, 4 veya 8 adet barındırılan malaklardan 8 'li barındırılanların yem tüketimi, CA ve vücut ölçülerinin daha yüksek olduğunu, bununla birlikte 8'li grupta diğer gruplara göre daha fazla solunum yolu hastalıklarının görüldüğünü saptamışlardır.

\section{Süt Mandacılığının Türkiye'deki Geleceği}

Türkiye'de manda yetiștiriciliği uzun yıllardan beridir geleneksel yöntemlerle yapılmakla birlikte 2012 yılında Türkiye Damızlık Manda Yetiştiricileri Merkez Birliği (TDMÜB) ve 28 ilde de şubeleri kurulduktan sonra bireysel çabalar bir çatı altında toplanıp daha bilimsel yollarla yapılmaya başlanılmıştır. Aynı zamanda son yıllarda devlet teşvikleriyle de maddi olarak desteklenmekte ve çiftçilere ek gelir sağlanmaktadır. İtalya'da 1979 yılında kurulan Ulusal Manda Türü Yetiştiricileri Derneği ile kıyaslandığında, iyileştirme çalışmalarında oldukça yeni olduğumuz görülmektedir. Ancak bu ülkelerin birikimlerinden yararlanılmak suretiyle de kısa sürede bazı iyileştirmelerin yapılabileceği bir de firsat bulunmaktadır. Türkiye'de manda üretimi ülkenin doğusundan batısına kadar pek çok ilinde yapılmaktadır. Aynı zamanda diğer hayvan türlerine göre manda üretimi konusunda yapılan bilimsel çalışma sayısı da sınırlıdır.

Manda üretimi bilhassa Asya ülkelerinde yaygındır ve buralarda geleneksel yöntemlerle ve daha çok ekstansif olarak yapılmaktadır (Pasha, 2013; Sarwar ve ark., 2009). Ülkemizde de mandalar geleneksel olarak küçük sürüler halinde ve modern olmayan bakım şartlarında ve mevsimin uygun olduğu dönemlerde daha çok meradan yararlanmaya yönelik yapılmakta, barınak olarak kışın kapalı alanlar kullanılmaktadır. Türkiye'de bulunan Anadolu mandaları, grubunda yer aldığı nehir manda gruplarından gerek Hindistan, Pakistan gibi Asya ülkelerinde yetiştirilen Mehsana, Nili-Ravi, Murrah gibi urklar ve gerekse
İtalya gibi Avrupa ülkelerinde üretilen Akdeniz mandalarında daha düşük canlı ağırlık ve süt verimine sahiptirler. Bilhassa İtalya gerek coğrafi konum yakınlığg ve bilgi alış-verişi için uygun olabileceği için Türkiye'deki çalışmaların bu bilgi kaynağını takibinde fayda vardır. Örneğin, İtalya'da 400.000 adet civarında manda entansif sistemde yetiştirilmekte ve dişiler padoklarda tutulmakta ve günde iki kez mekanik olarak sağılmaktadırlar. Manda erkekleri ise yoğun besiye alınmaktadırlar veya 1zgaralı zemin ahırlarında beslenmektedirler ve 15 aylık yaşta kesilerek 400 kg'dan fazla canlı ağırlık elde edilmektedir (Borghese, 2013).

Asya ülkelerinde yetiştirilen mandalardan elde edilen gelir İtalya'ya göre oldukça düşük düzeydedir. İtalya bu başarısını, ülkedeki çok sayıdaki hayvanın verim, seleksiyon, genetik ve üreme performansı, sağlık, yemleme ve yetiştiricilik kayıtlarını iyi bir şekilde tutmasına borçludur. Hayvanların bu parametreler yanında sütteki yağ ve protein içeriği kayıtları da tutularak değerlendirmeler yapılmaktadır. Bu sayede 270 günlük laktasyon süresinde $5000 \mathrm{~kg}$ süt veren çok sayıda manda bulunmakta, hatta laktasyonda $\% 8,32$ yăg ve $\% 4,63$ proteinli $5600 \mathrm{~kg}$ süt üreten rekor hayvanlar elde edilmiştir (Borghese, 2013).

Sonuç olarak, ıslah çalışmaları uzun yıllar alan çalışmalardır. İtalya'daki yakalanan başarıya benzer bir başarının elde edilebilmesi için öncelikle ülkemizdeki mandaların iyi bakım ve yönetim şartları altında verim ve üreme kayıtları başta olmak üzere elde edilebilecek tüm kayıtların tutulmasına gereksinim vardır. Elde edilen kayıtların değerlendirilerek ıslah yöntemlerinin kesintisiz olarak sürdürülmesi ve gen kaynaklarının kaybedilmemesi gereklidir.

Diğer yandan, son 20-30 yıllık dönemde süt sığırcılığında yerli ırkların 1slahında hem kültür melezi boğa ve hem de spermaları kullanılmak suretiyle, birim hayvandan elde edilen verim önemli miktarda artırılmıştır. Sı ğırlarda verim artışında elde edilen başarıya benzer şekilde mandalarda da başta süt verimi olmak üzere ıslah çalışmaları sonucunda elde edilen gen kaynaklarının (canlı hayvan veya sperma) kullanımı gereklidir.

\section{Kaynakça}

Abbas, W., Bhatti, S. A., Khan, M. S., Saeed, N., Warriach, H. M., Wynn, P., \& McGill, D. (2017). Effect of weaning age and milk feeding volume on growth performance of Nili-Ravi buffalo calves. Italian Journal of Animal Science, 16 (3). https://doi.org/10.1080/1828051X.2017.1291282

Ahmad, S., Gaucher, I., Rousseau, F., Beaucher, E., Piot, M., Grongnet, J. F., \& Gaucheron, F. (2008). Effects of acidification on physico-chemical characteristics of buffalo milk: A comparison with cow's milk. Food Chemistry, 106(1). https://doi.org/10.1016/j.foodchem.2007.04.021

Aksoy, A., Haşimoğlu, S., \& Çakır, A. (1981). Besin Maddeleri ve Hayvan Besleme. Atatürk Universitesi Ziraat Fakültesi Basımevi.

Alkoyak, K., \& Öz, S. (2020). The Effect of Some Environmental Factors on Lactation Length, Milk Yield and Calving Intervals of Anatolian Buffaloes in Bartın Province of Turkey. Lalahan Hayvancılık Araştırma Enstitüsü Dergisi, 60(2), 54 61. https://doi.org/10.46897/livestockstudies.846415

Allegrini, S., Mazzi, M., Roncoroni, C., Alfieri, L., Campagna, M. C., \& Borghese, A. (2007). Morphometric and haematological parameters in Italian Mediterranean Buffaloes finished with different diets. Italian Journal of Animal Science, 6(Suppl. https://doi.org/10.4081/ijas.2007.s2.512

Ambardekar, D. V. (2000). Studies on body measurement and 
qualitative traits in Pandharpuri buffaloes. M. Sc. (Agri.) Thesis, Mahatma Phule Agricultural University, Rahuri, M.S., India.

Andersen, J. B., Sehested, J., \& Ingvartsen, K. L. (1999). Effect of dry cow feeding strategy on rumen $\mathrm{pH}$, Concentration of volatile fatty acids and rumen epithelium development. Acta Agriculturae Scandinavica A: Animal Sciences, 49(3). https://doi.org/10.1080/090647099424051

Aref, N. E. M., El-Sebaie, A., \& Hammad, H. Z. (2016). New insights on ill-thriftiness in early-weaned buffalo calves. Veterinary World, 9(6). https://doi.org/10.14202/vetworld.2016.579-586

Aspilcueta-Borquis, R. R., Araujo Neto, F. R., Baldi, F., Santos, D. J. A., Albuquerque, L. G., \& Tonhati, H. (2012). Genetic parameters for test-day yield of milk, fat and protein in buffaloes estimated by random regression models. Journal of Dairy Research, 79(3). https://doi.org/10.1017/S0022029912000143

Barbosa, S. B. P., Modesto, E. C., Lopes, F. de A., da Silva, E. C., \& Abad, A. C. A. (2020). Relationship between milk production system and milk traits and somatic cell counts in brazilian murrah buffaloes: A multivariate analysis. Acta Scientiarum - Animal Sciences, 42(1). https://doi.org/10.4025/actascianimsci.v42i1.46522

Bharadwaj, A., Dixit, V. B., Sethi, R. K., \& Khanna, S. (2007). Association of breed characteristics with milk production in Murrah buffaloes. Indian Journal of Animal Sciences, 77(10).

Bharti, P. K., Dutt, T., Pandey, H. O., Patel, B. H. M., Mahendran, K., Kaswan, S., Upadhyay, V. K. (2015). Effect of weaning age on health of Murrah buffalo calves. Indian Journal of Animal Sciences, 85(12).

Bhatti, J. A., Younas, M., Abdullah, M., Babar, M. E., \& Nawaz, H. (2009). Feed intake, weight gain and haematology in niliravi buffalo heifers fed on mott grass and berseem fodder substituted with saltbush (atriplex amnicola). Pakistan Veterinary Journal, 29(3).

Bhatti, S. A., Ahmed, M. F., Wynn, P. C., McGill, D., Sarwar, M., Afzal, M., ... Khan, A. (2012). Effect of diet on preweaning performance of Sahiwal calves. Tropical Animal Health and Production, 44(4). https://doi.org/10.1007/s11250-011-99733

Bilal, M. Q., Suleman, M., \& Raziq, A. (2006). Buffalo: Black gold of Pakistan. Livestock Research for Rural Development. 18(9), 140-151.

Borghese, A. (2005). Buffalo Production and Research. Food and Agriculture Organization of the United Nations (Vol. 5). https://doi.org/10.4081/ijas.2006.203

Borghese, A. (2013). Buffalo livestock and products in Europe. Buffalo Bulletin, 32(Spec. Issue 1).

Boselli, C., Mazzi, M. M., Borghese, A., Terzano, G. M., Giangolini, G., Filippetti, F., Rosati, R. (2010). Milk flow curve and teat anatomy in mediterranean Italian buffalo cows. Revista Veterinaria, 21(Suppl.1).

Ceniti, C., Britti, D., Trimboli, F., Morittu, V. M., Lopreiato, V., \& Costanzo, N. (2019). Evaluation of freezing point in milk from buffalos reared in Calabria, Italy. Italian Journal of Food Safety, 8(2). https://doi.org/10.4081/ijfs.2019.7895

Chantalakhana, C., \& Bunyavejchewin, P. (1994). Buffaloes and draught power. Outlook on Agriculture, 23(2). https://doi.org/10.1177/003072709402300204

Charlini, B. C., \& Sinniah, J. (2015). Performance of Murrah, Surti, Nili-Ravi buffaloes and their crosses in the intermediate zone of Sri Lanka. Livestock Research for Rural
Development, 27(3).

Coroian, A., Erler, S., Matea, C. T., Miresan, V., Răducu, C., Bele, C., \& Coroian, C. O. (2013). Seasonal changes of buffalo colostrum: Physicochemical parameters, fatty acids and cholesterol variation. Chemistry Central Journal, 7(1), 1-9. https://doi.org/10.1186/1752-153X-7-40

Costa, A., De Marchi, M., Battisti, S., Guarducci, M., Amatiste, S., Bitonti, G., ... Boselli, C. (2020). On the Effect of the Temperature-Humidity Index on Buffalo Bulk Milk Composition and Coagulation Traits. Frontiers in Veterinary Science, 7. https://doi.org/10.3389/fvets.2020.577758

de la Cruz-Cruz, L. A., Bonilla-Jaime, H., Orozco-Gregorio, H., Tarazona-Morales, A. M., Ballesteros-Rodea, G., RoldanSantiago, P., Vargas-Romero, J. M. (2019). Effects of weaning on the stress responses and productivity of water buffalo in different breeding systems: A review. Livestock $\begin{array}{llll}\text { Science. } & 226 & \text { (2019): } & \text { 73-81. }\end{array}$ https://doi.org/10.1016/j.livsci.2019.05.020

Degirmencioglu, T., Unal, H., \& Kuraloglu, H. (2015). Comparison of extensive or semi-intensive feeding for Anatolian water buffalo. Emirates Journal of Food and Agriculture, 27(9), 712-715. https://doi.org/10.9755/ejfa.2015.04.07

Drost, M. (2007). Bubaline versus bovine reproduction. Theriogenology, https://doi.org/10.1016/j.theriogenology.2007.04.012

Ekiz, B., Yilmaz, A., Yalcintan, H., Yakan, A., Yilmaz, I., \& Soysal, I. (2018). Carcass and Meat Quality of Male and Female Water Buffaloes Finished under an Intensive Production System. Annals of Animal Science, 18(2). https://doi.org/10.1515/aoas-2017-0036

El-Barody, M. A. A., Daghash, H. A., \& Rabie, Z. B. H. (2001). Some physiological responses of pregnant Egyptian buffalo to niacin supplementation. Livestock Production Science, 69(3). https://doi.org/10.1016/S0301-6226(01)00169-5

FAOStat. (2019). Food and Agricultural Organization. Animal Production Data. Erişim: 02.03.2021.

Galsar, N. S., Shah, R. R., Gupta, J. P., Pandey, D. P., \& Patel, K. B. (2016). Analysis of first production and reproduction traits of Mehsana buffaloes maintained at tropical and semi-arid region of Gujarat, India. Life Sciences Leaflets, 4297(77), 65-75.

Ghaffar, A., Ansari, M. H., Jokhio, M. H., \& Bhutto, N. M. (2007). Genetic analysis of a purebred herd of Kundhi buffaloes in Pakistan. Italian Journal of Animal Science, 6(Suppl. 2). https://doi.org/10.4081/ijas.2007.s2.271

Gwazdauskas, F. C., Wilcox, C. J., \& Thatcher, W. W. (1975). Environmental and Managemental Factors Affecting Conception Rate in a Subtropical Climate. Journal of Dairy Science, 58(1). https://doi.org/10.3168/jds.S00220302(75)84523-1

Hamid, M. A., Ahmed, S., Rahman, M. A., \& Hossain, K. M. (2016). Status of buffalo production in Bangladesh compared to SAARC countries. Asian Journal of Animal Sciences, 10(6), 313-329. https://doi.org/10.3923/ajas.2016.313.329

Hamid, M., Siddiky, M., Rahman, M., \& Hossain, K. (2017). Scopes and opportunities of buffalo farming in Bangladesh: A review. SAARC Journal of Agriculture, 14(2). https://doi.org/10.3329/sja.v14i2.31246

Helal, F. I. S., \& Abdel- Rahman, K. A. (2010). Productive performance of lactating ewes fed diets supplementing with dry yeast and/or bentonite as feed additives. World Journal of Agricultural Sciences. 
Hofi, M. (2013). Buffalo milk cheese. Buffalo Bulletin. 32(Special Issue 1), 355-360.

Iannuzzi, L. (2013). Evolutionary, clinical and molecular cytogenetics in water buffalo: An update. Buffalo Bulletin, 32(SPEC. ISSUE 1), 244-256.

Jabbar, M., Fiaz, M., Abdullah, M., Sciences, A., Marghazani, I. B., \& Sciences, M. (2013). Effect of Different Dietary Energy Levels on Milk Production in Lactating Nili -Ravi Buffaloes. Journal of Animal and Plant Sciences, 23(1 Supplement), 1316.

Javed, K., Abdullah, M., Khalid, M. S., Ahmad, N., Bhatti, J. A., \& Younas, U. (2013). Inter-relationship of milk constituents with body and udder measurements in Nili-Ravi buffaloes raised at commercial farms of Pakistan. In Buffalo Bulletin (Vol. 32).

Kapadiya, D. B., Prajapati, D. B., Jain, A. K., Mehta, B. M., Darji, V. B., \& Aparnathi, K. D. (2016). Comparison of Surti goat milk with cow and buffalo milk for gross composition, nitrogen distribution, and selected minerals content. $\begin{array}{ll}\text { Veterinary } \quad \text { World, } & \text { 9(7). }\end{array}$ https://doi.org/10.14202/vetworld.2016.710-716

Khan, M. S., Ahmad, N., \& Khan, M. A. L. I. (2007). Genetic resoursec and diversity in dairy buffaloes in Pakistan. Pakistan Veterinary Journal, 27(4).

Koçak, S., Tekerli, M., Çelikeloğlu, K., Erdoğan, M., Bozkurt, Z., \& Hacan. (2019). An investigation on yield and composition of milk, calving interval and repeatabilities in riverine buffaloes of anatolia. Journal of Animal and Plant Sciences, 29(3).

Kumar, A., Kamboj, M. L., Kumar, S., Jingar, S. C., Lawania, P., \& Bugaliya, H. L. (2017). Performance of Murrah Buffalo and their Calves under Weaning and Suckling System. International Journal of Current Microbiology and Applied Sciences, 6(7). https://doi.org/10.20546/ijcmas.2017.607.348

Kumar Singh, P., Chandra Scholar, S., Kumar Singh, R., Pankaj Kumar Singh, C., Kamboj, M., \& Chandra, S. (2017). Effect of calf suckling dummy calf used and weaning on milk ejection stimuli and milk yield of Murrah buffaloes (Bubalus bubalis). 1012 Journal of Pharmacognosy and Phytochemistry, 6(6S).

Marai, I. F. M., Daader, A. H., Soliman, A. M., \& El-Menshawy, S. M. S. (2009). Non-genetic factors affecting growth and reproduction traits of buffaloes under dry management housing (in sub-tropical environment) in Egypt. Livestock Research for Rural Development, 21(3).

Medhammar, E., Wijesinha-Bettoni, R., Stadlmayr, B., Nilsson, E., Charrondiere, U. R., \& Burlingame, B. (2012). Composition of milk from minor dairy animals and buffalo breeds: A biodiversity perspective. Journal of the Science of Food and Agriculture. https://doi.org/10.1002/jsfa.4690

Misra, S. S., Sharma, A., Bhattacharya, T. K., Kumar, P., \& Roy, S. S. (2008). Association of breed and polymorphism of $\alpha$ and $\alpha$-casein genes with milk quality and daily milk and constituent yield traits of buffaloes (bubalus bubalis). Buffalo Bulletin, 27(4).

Mohran, M. A. (1991). Effect of Stage of Lactation on the Physical and. Egyptian . J. Dairy Sci, 77-82.

Moioli, B., \& Borghese, A. (2005). Buffalo Breeds and Management Systems. Buffalo Production and Research.

Mota-Rojas, D., De Rosa, G., Mora-Medina, P., Braghieri, A., Guerrero-Legarreta, I., \& Napolitano, F. (2019). Dairy buffalo behaviour and welfare from calving to milking. CAB Reviews: Perspectives in Agriculture, Veterinary Science,
Nutrition and Natural Resources,

14. https://doi.org/10.1079/PAVSNNR201914035

Nanda, A. S., \& Nakao, T. (2003). Role of buffalo in the socioeconomic development of rural Asia: Current status and future prospectus. Animal Science Journal. https://doi.org/10.1046/j.1344-3941.2003.00138.x

Naveena, B. M., \& Kiran, M. (2014). Buffalo meat quality, composition, and processing characteristics: Contribution to the global economy and nutritional security. Animal Frontiers, 4(4), 18-24. https://doi.org/10.2527/af.2014-0029

Nawaz, H., Yaqoob, M., \& Abdullah, M. (2007). Effect of feeding supplemental tallow on the performance of lactating NiliRavi buffaloes. Turkish Journal of Veterinary and Animal Sciences, 31(6).

Nayyar, S., Gill, V. K., Singh, N., Roy, K. S., \& Singh, R. (2002). Levels of antioxidant vitamins in anoestrus buffalo heifers supplemented with vitamin E and selenium. Indian Journal of Animal Sciences, 72(5).

Panda, N., Kaur, H., \& Mohanty, T. K. (2006). Reproductive performance of dairy buffaloes supplemented with varying levels of vitamin E. Asian-Australasian Journal of Animal Sciences, 19(1). https://doi.org/10.5713/ajas.2006.19

Pasha, T. N. (2013). Prospect of nutrition and feeding for sustainable buffalo production. Buffalo Bulletin, 32(Spec. Issue 1).

Patil, A., Disouza, J., \& Pawar, S. (2019). Evaluation of lactobacillus plantarum growth in milk of indian buffalo breeds based on its physico-chemical content. Buffalo Bulletin, 38(2).

Patiño, E. ., \& Guaziroli, E. (2005). Composición de leche de búfala (Bubalus bubalis) de raza Jafarabadi en Corrientes, Argentina (Buffalo (Bubalus bubalis) milk composition of Jafarabadi in Corrientes, Argentina). Revista Electronica de Veterinaria Redvet, 6(5).

Paul, S. S., Mandal, A. B., Kannan, A., Mandal, G. P., \& Pathak, N. N. (2003). Comparative dry matter intake and nutrient utilisation efficiency in lactating cattle and buffaloes. Journal of the Science of Food and Agriculture, 83(4). https://doi.org/10.1002/jsfa.1305

Phogat, J., Pandey, A. K., \& Singh, I. (2016). Seasonality in buffaloes reproduction. International Journal of Plant, Animal Environmental Sciences, 6(2).

Purohit, G. N., Kumar, P., Solanki, K., Shekher, C., \& Yadav, S. P. (2012). Perspectives of fetal dystocia in cattle and buffalo. Veterinary Science Development, 2(1). https://doi.org/10.4081/vsd.2012.e8

Qureshi, M. S., Habib, G., Samad, H. A., Siddiqui, M. M., Ahmad, N., \& Syed, M. (2002). Reproduction-nutrition relationship in dairy buffaloes. I. Effect of intake of protein, energy and blood metabolites levels. Asian-Australasian Journal of Animal Sciences, https://doi.org/10.5713/ajas.2002.330

$15(3)$.

Rafiuddin, N. A., Moaeen-ud-Din, M., Babar, M. E., Abdullah, M., Jabbar, M. A., Khan, F. S., ... Bhatti, J. A. (2009). Effect of Group Size on Growth Performance of Nili Ravi Buffalo Calves during Winter Months. Pakistan J. Zool. Suppl. Ser., 9(9), 613-618.

Ranjhan, S. K. (2007). Buffalo as a social animal for humanity. Italian Journal of Animal Science, 6(SUPPL. 2). https://doi.org/10.4081/ijas.2007.s2.30

Rashid, M. A., Pasha, T. N., Jabbar, M. A., Ijaz, A., Rehman, H., \& Yousaf, M. S. (2013). Influence of weaning regimen on intake, growth characteristics and plasma blood metabolites 
in male buffalo calves. Animal, 7(9). https://doi.org/10.1017/S1751731113000943

Rathod, A., Vaidya, M., \& Ali, S. (2018). Genetic Studies of Productive and Reproductive Attributes of Surti Buffalo in Maharashtra. International Journal of Livestock Research, 8(5). https://doi.org/10.5455/ijlr.20171016061752

Raval, A., Sorathiya, L., Katariya, M., Kharadi, V., Patel, V., Patel, N., \& Parmar, A. (2019). Effect of Challenge Feeding on Production Performance of Surti Buffaloes. International Journal of Livestock Research, (0). https://doi.org/10.5455/ijlr.20190508112036

Rosati, A., \& Van Vleck, L. D. (2002). Estimation of genetic parameters for milk, fat, protein and mozzarella cheese production for the Italian river buffalo Bubalus bubalis population. Livestock Production Science, 74(2). https://doi.org/10.1016/S0301-6226(01)00293-7

Sabia, E., Napolitano, F., Claps, S., Braghieri, A., Piazzolla, N., \& Pacelli, C. (2015). Feeding, nutrition and sustainability in dairy enterprises: The case of Mediterranean Buffaloes (Bubalus Bubalis). In The Sustainability of Agro-Food and Natural Resource Systems in the Mediterranean Basin. https://doi.org/10.1007/978-3-319-16357-4_5

Sahin, A., Yıldırım, A., \& Ulutas, Z. (2016). Changes in some physico-chemical content of Anatolian buffalo milk according to the some environmental factors. Buffalo Bulletin, 35(4).

Salari, F., Altomonte, I., \& Martini, M. (2013). Buffalo milk: A case study of some parameters related to milk production. Large Animal Review, 19(1).

Sannino, M., Faugno, S., Crimaldi, M., Di Francia, A., Ardito, L., Serrapica, F., \& Masucci, F. (2018). Effects of an automatic milking system on milk yield and quality of Mediterranean buffaloes. Journal of Dairy Science, 101(9). https://doi.org/10.3168/jds.2017-14157

Sarwar, G., \& McDonough, F. E. (1990). Evaluation of protein digestibility-corrected amino acid score method for assessing protein quality of foods. J Assoc Off Anal Chem, 73(3), 347356.

Sarwar, M., Khan, M. A., Nisa, M., Bhatti, S. A., \& Shahzad, M. A. (2009). Nutritional management for buffalo production. Asian-Australasian Journal of Animal Sciences, 22(7). https://doi.org/10.5713/ajas.2009.r.09

Şekerden, Ö., Borghese, A., Köroğlu, M., Uras, H., \& Güzey, Y. Z. (2005). Anadolu Mandalarında Sun'i Tohumlama Çalışmaları ve PRID (Progesterone Releasing Intravaginal Device) Uygulamanın Döl Tutma Oranı Üzerine Etkisi. Tarım Bilimleri Dergisi, 11(2), https://doi.org/10.1501/tarimbil_0000000420

Şekerden, Ö., \& Küçükkebapçı, M. (1999). Afyon Kocatepe Tarimsal AraştirmaEnstitüsü Anadolu Mandalarinda Süt Verim Bileşiminin Laktasyon Dönemlerine Göre Değişimi, Süt ve Bazi Döl Verim Özellikleri. Atatürk Üniversitesi Ziraat Fakültesi Dergisi, 30(2), 151-159. https://doi.org/10.17097/zfd.73087

Siddiky, M., \& Faruque, M. (2018). Buffaloes for dairying in South Asia: potential, challenges and way forward. SAARC Journal of Agriculture, 15(2). https://doi.org/10.3329/sja.v15i2.35167

Soysal, M. I. (2013). Anatolian water buffaloes husbandry in Turkey. Buffalo Bulletin, 32(SPEC. ISSUE 1).

Soysal, M. İ., Genç, S., Aksel, M., Ünal, E. Ö., \& Gürcan, E. K. (2018). Effect of Environmental Factors on Lactation Milk Yield, Lactation Length and Calving Interval of Anatolian
Buffalo in Istanbul İstanbul ' da Yetiştirilen Anadolu Mandalarının Laktasyon Süt Verimi , Laktasyon Uzunluğu ve Buzağılama Aralığı Üzerine Çevres. Journal of Animal Science and Products, 1(1), 93-97.

Terramoccia, S., Bartocci, S., Amici, A., \& Martillotti, F. (2000). Protein and protein-free dry matter rumen degradability in buffalo, cattle and sheep fed diets with different forage to concentrate ratios. Livestock Production Science, 65(1-2). https://doi.org/10.1016/S0301-6226(99)00155-4

Thomas, C. S., Svennersten-Sjaunja, K., Bhosrekar, M. R., \& Bruckmaier, R. M. (2004). Mammary cisternal size, cisternal milk and milk ejection in Murrah buffaloes. Journal of Dairy Research, $71(2)$. https://doi.org/10.1017/S0022029904000081

TNAU. (2020). Livestock, Buffalo, Feeding. https://agritech.tnau.ac.in/animal_husbandry/animhus_buffal o\%20feeding.html Erişim:02.06. 2021

TÜİK. (2020). Türkiye İstatistik Kurumu (TÜİK) Hayvansal Üretim İstatistikleri. Ankara.

Uğurlu, M., Kaya, I., \& Saray, M. (2016). Effects of some environmental factors on calf birth weight and milk yield of Anatolian Water Buffalo (Bubalus bubalis). Bulgarian Journal of Agricultural Science, 22(6).

Wang, J., He, Y., Pang, K., Zeng, Q., Zhang, X., Ren, F., \& Guo, H. (2019). Changes in milk yield and composition of colostrum and regular milk from four buffalo breeds in China during lactation. Journal of the Science of Food and Agriculture, 99(13). https://doi.org/10.1002/jsfa.9849

Warriach, H. M., McGill, D. M., Bush, R. D., Wynn, P. C., \& Chohan, K. R. (2015). A review of recent developments in buffalo reproduction - A review. In Asian-Australasian Journal of Animal Sciences (Vol. 28). https://doi.org/10.5713/ajas.14.0259

Wynn, P. C., Warriach, H. M., Morgan, A., McGill, D. M., Hanif, S., Sarwar, M., Bush, R. D. (2009). Perinatal nutrition of the calf and its consequences for lifelong productivity. AsianAustralasian Journal of Animal Sciences, 22(5). https://doi.org/10.5713/ajas.2009.r.06

Yavasoglu, N. U. K., Koksal, C., Yaman, Y., \& Un, C. (2014). Karyotype of Anatolian water buffalo (Bubalus bubalis). Buffalo Bulletin, 33(4), 337-342.

Yilmaz, A., Ocak, E., \& Kose, S. (2017). A research on milk yield, milk composition and body weights of Anatolian buffaloes. Indian Journal of Animal Research, 51(3). https://doi.org/10.18805/ijar.11474

Zhou, L., Tang, Q., Wasim Iqbal, M., Xia, Z., Huang, F., Li, L., Zou, C. (2018). A comparison of milk protein, fat, lactose, total solids and amino acid profiles of three different buffalo breeds in Guangxi, China. Italian Journal of Animal Science, 17(4). https://doi.org/10.1080/1828051X.2018.1443288

Zicarelli, L., Ariota, B., Gasparrini, B., Neglia, G., \& Di Palo, R. (2007). Buffalo beef production. Italian Journal of Animal Science, 6(Suppl.

https://doi.org/10.4081/ijas.2007.s2.1312

Zicarelli, Luigi. (2020). Considerations on the breeding and weaning of buffalo calf. Journal of Buffalo Science, 9. https://doi.org/10.6000/1927-520X.2020.09.11 